\title{
Non-colonial coral macro-borers as indicators of coral reef status in the south Pacific of Costa Rica
}

\author{
A.C. Fonseca E. ${ }^{1}$, H.K. Dean ${ }^{2} \&$ J. Cortés ${ }^{1}$ \\ 1 Centro de Investigación en Ciencias del Mar y Limnología (CIMAR). Universidad de Costa Rica, San Pedro. San José \\ 2060, Costa Rica; afonseca@cariari.ucr.ac.cr; jcortes@cariari.ucr.ac.cr \\ 2 Dept. of Invertebrate Zoology, Harvard University, 26 Oxford St. Cambridge, MA 02138; hdean1@mindspring.com
}

Received 29-VI-2005. Corrected 31-VIII-2005. Accepted 28-IX-2005.

\begin{abstract}
Coral reef status was surveyed in three south Pacific coral reefs of Costa Rica, one in Caño Island and two in Golfo Dulce, and the density, richness and distribution of non-colonial macro borers ( $>1 \mathrm{~mm})$ was determined in dead and live coral fragments from these reefs. Based upon traditional indicators of degradation such as high particulate suspended matter and low live coral cover, the reefs at Caño Island are in better condition than those at Golfo Dulce. Reef degradation in Golfo Dulce is mainly due to high loads of terrestrial sediments as a consequence of watersheds deforestation. In this study, 36 coral boring species are reported for the eastern Pacific. At the family level, there is high endemism (10\%) and greater affinity with the Indo-Pacific (34\%), as compared with the eastern Atlantic and Mediterranean (29\%) and western Atlantic and Caribbean (27\%). The dominant non-colonial macro boring families at the study reefs are mytilid bivalves, eunicid polychaetes and aspidosiphonid sipunculans, with the bivalves considered the main internal bioeroders due to their greater body size and abundances. The level of mortality of the coral colonies and the general level of reef degradation influenced the composition of non-colonial macro-borers. Diversity and total macro-borer density, especially aspidosiphonid density, is higher in corals with greates dead than live cover. In the healthiest coral colonies (less than $50 \%$ of partial mortality), mytilids domination, macro-borer diversity and total density, is higher in Golfo Dulce, where reefs are more degraded. In the most affected coral colonies (more than $50 \%$ dead), macro-borers total density, especially aspidosiphonids density, is higher, of the healthiest reef of this study, Platanillo. Bivalve relative abundance increases and sipunculan relative abundance decreases with increasing site degradation. In conclusion bioeroder variables can also be used as reef health indicators. Rev. Biol. Trop. 54(1): 101-115. Epub 2006 Mar 31.
\end{abstract}

Keywords: Borers, bioerosion, coral reef, Costa Rica, Caño Island, Golfo Dulce, eastern Pacific, sediment.

Dreaming about boring a tunnel to escape from prison? Dreaming about boring a reef and discover its formation history?

Dreaming about boring a being to posses it? Dreaming about boring an oil pit that attaches us to money? Or Dreaming about boring a skeleton to keep enclosed? It's finally just dreaming about "boring to cope with boredom". (Inspired in the movie "Shawshank Redemption" produced by Niki Marvin and directed by Frank Darabont; based on the novel of the same title written by Stephen King)

Borers are agents of bioerosion inside dead and live coral making it more susceptible to physical erosion (MacGeachy and Stearn 1976, Highsmith 1981a, Highsmith et al. 1983, Kiene 1988, Scott and Risk 1988).
Boring mechanisms have been extensively studied; they are mechanical and/or chemical depending on borer species (Kleeman 1990, Hutchings et al. 1992, Glynn 1997). The boring strategy must confer a high level of 
protection to the organism to offset the high cost of boring (Rice 1969).

The relation between corals and borers is still debatable. Borers could be parasites of their coral hosts or they could have a mutual symbiosis. The benefits of substrate and protection provided by the coral to the borers are clear, however, the reverse, is not so obvious. It is possible that live coral borers favour asexual reproduction of corals due to fragmentation (Scott et al. 1988, Guzmán and Cortés 1989b, Cortés 1997). Another possibility is that corals could be consuming nutrients such as ammonium from the waste products of the borers (Mokady et al. 1998).

Carbonate bioerosion is common and is in delicate balance with carbonate production in healthy reefs (Scoffin et al. 1980, Glynn 1988). In disturbed reefs, however, internal and external bioerosion processes are known to destroy the reef framework faster than it is produced (Hutchings 1986, Eakin 1992, 1996, Peyrot-Clausade et al. 1992, Pari et al. 1998).

Quantitative information about the biological, physical and chemical factors that determine borer distributions, density and activity are lacking especially in the eastern Pacific. Boring rates are variable and depend on borer species, coral density and other physical and chemical factors such as nutrient concentration and depth (Highsmith 1980, Smith et al. 1981, Brock and Smith 1983, Hutchings 1986, Glynn 1997, Pari et al. 1998, Perry 1998, Chazottes et al. 2002, Londoño et al. 2003). There is no agreement, however, as to how factors such as depth and coral density affect borer abundance and activity. What is generally accepted is that dead coral surface is preferentially attacked by bio-eroders (Highsmith 1980, 1981) thus any factor that kills corals favors bioerosion. We know that coral reefs, especially those of continental coasts, have been dying worldwide due to terrestrial and organic sediment loads resulting from deforested soil drainage (Hughes et al. 2003), so not only are corals not constructing more reef, but also the framework of the reef is being lost due to bioerosion of dead substrate.

Eighteen coral macro-borer species in four phyla (Sipuncula, Mollusca, Crustacea and Porifera) have been reported for the eastern Pacific by Fonseca and Cortés (1998). Four other bivalves, Lithophaga spatiosa (Keen 1971, Kleemann 1990), L. calyculata, L. hastasia (Cantera et al. 2003), Leiosolenus hanckoki (Keen 1971, Cantera and Contreras 1988, Kleeman 1990), and four sipunculans, Aspidosiphon steenstrupii, Paraspidosiphon klunzingeri (synonym of $P$. laevis, but we suspect that this species could be P. coyi), Phascolosoma puntarenae and Sipunculus sp. (Cantera et al. 2003) were later found in the literature. The polychaete species marked as potential borers by Cantera et al. (2003) should be considered as potential bioeroders, with the exception of Eunice sp. which could be a borer, and Flabelligera sp. which are not reported as bioeroders.

\section{A}

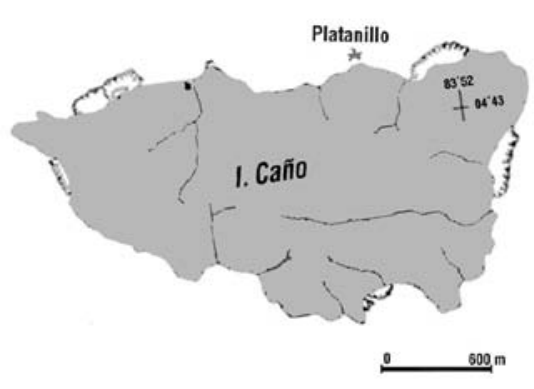

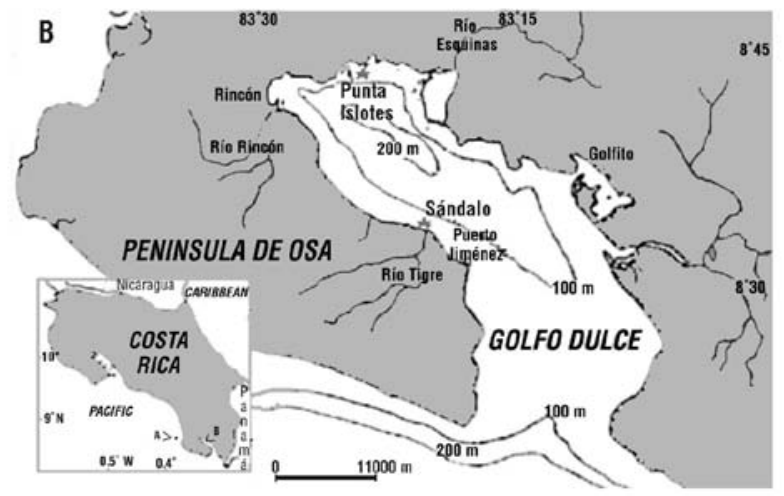

Fig. 1. Sampling sites (stars): A. Platanillo reef at Caño Island (modified from Guzmán and Cortés 1989b); B. Punta Islotes and Sándalo reefs in Golfo Dulce (modified from Fonseca and Cortés 1998). 
The Galapagos Islands, Gorgona Islands, Caño Island and Panama are the sites in the eastern Pacific with the highest reported number of identified borer species (Fonseca and Cortés 1998, Cantera et al. 2003). In this study, data on density, richness, distribution and biogeographic affinities is provided for the non-colonial macro-borers $(>1 \mathrm{~mm})$ from three coral reefs of the south Pacific of Costa Rica, differing in their levels of reef degradation.

\section{MATERIALS AND METHODS}

The non-colonial macro-borers $(>1 \mathrm{~mm})$ of three reefs in the south Pacific of Costa Rica were studied: Platanillo at Caño Island, and Punta Islotes and Sándalo at Golfo Dulce (Fig. 1).

\section{Site descriptions}

\section{Platanillo reef, Caño Island}

Caño Island is located $15 \mathrm{~km}$ from the mainland and has an area of 300 ha, a maximum altitude of $90 \mathrm{~m}$ is and covered by tropical rain forest. This low island and the waters within $3 \mathrm{~km}$ around it are protected as a Biological Reserve. Platanillo is a fringing reef located in the north side of Caño Island $\left(8^{\circ} 42^{\prime} 53^{\prime \prime} \mathrm{N}\right.$; 8352'35" W). This reef has a maximum depth of $10 \mathrm{~m}$, and is dominated by Porites lobata. Platanillo has strong surge and tidal currents and sandy sediments are constantly re-suspended by the waves (Guzmán and Cortés 1989a).

\section{Punta Islotes and Sándalo reefs, Golfo Dulce}

Golfo Dulce is an estuary $50 \mathrm{~km}$ long and 10 to $15 \mathrm{~km}$ wide with an area of $680 \mathrm{~km}^{2}$ (Fig. 1). The maximum depth is $200 \mathrm{~m}$ and there is a sill 50 to $60 \mathrm{~m}$ deep at its mouth constituting a barrier to mixing (Cortés 1990). Most rivers that flow into Golfo Dulce are small, have pronounced, deforested slopes, and high suspended fine sediments load (Umaña 1998). The waters of Golfo Dulce are calm but the terrestrial and organic clay component is high, especially at shallow sites (Hebbeln et al. 1996), so they are easily resuspended.

Punta Islotes is located in the north internal side of Golfo Dulce (8'43'41" N; 8323'8" W), 5 to $6 \mathrm{~km}$ from the Esquinas River (Fig. 1). This fringing reef has an area of 12 ha, reaches a maximal depth of $12 \mathrm{~m}$, and has a mean thickness of 9 m (Cortés 1991, Cortés et al. 1994) which is high in comparison with other eastern Pacific reefs (Macintyre et al. 1992). This reef is dominated by P. lobata (Cortés 1991).

Sándalo is located in the south east side of Golfo Dulce (8'34'28' N; 8320'15" W) within 0.5 and $1 \mathrm{~km}$ west of the Tigre River mouth (Fig. 1). This is also a fringing reef with an area of 5 ha and a maximum depth of $6 \mathrm{~m}$ dominated by P. lobata (Cortés 1992).

\section{Reef relative cover, coral diversity and structural relief}

The relative cover of the substrate and reef relief was assessed with nineteen linear chain transects per site, $10 \mathrm{~m}$ long, from 3 to $12 \mathrm{~m}$ deep, depending on the structure of the reef. The number of chain links per substrate was counted and the data was normalized with the square root of the counts for the multivariate analysis of variances (MANOVA) between sites.

Following transformation, the error variance of the variables dead coral $(p=0.32)$ and sediment $(p=0.79)$, after the Levene's Test, was equalized across the sites; the error variance of live coral, algae and others was still not equal across sites $(p<0.05)$. Since there was correlation between the dependent variables, using the Bartlett's test $(p<0.05)$, the main effects of the group sites were tested by MANOVA, using Wilks' Lambda test. The pair wise comparison between sites was done by the Bonferroni test with a significance level of $0.05 \%$.

The structural relief was calculated from these transects as the ratio between the chain length in a straight line $(10 \mathrm{~m})$ and the chain length over the substrate (Risk 1972). Corals diversity by site was estimated with the Shannon-Wienner diversity index (H') (log 
base 2). The results were normalized with logarithm $(\log \mathrm{M})$. Following transformation the error variance of both variables, corals diversity $(p=0.19)$ and relief $(p=0.94)$, after the Levene's Test, was equalized across the sites. Since the Bartlett's test was significant $(\mathrm{p}<0.05)$, the significance of differences between sites was tested by MANOVA, using the Wilks' Lambda test. The pair wise comparison between sites was done by the Bonferroni test with a significance level of $0.05 \%$.

\section{Water and sediment physical and chemical analyses}

Water physical and chemical variables were assessed for two years. Water temperature was measured with a mercury thermometer, salinity with a refractometer, and visibility with a Secchi disk. The granulometric analysis was done with standard methods using the following sieve sizes: $9.500,4.000,2.000,1.000$, $0.850,0.600,0.425,0.300,0.250,0.180,0.125$ and $0.075 \mathrm{~mm}$. Sediment classification was determined after Dean et al. (1985). The percent of organic matter was estimated with the titration method of Walkey and Black (1938). The thickness of the clay layer over the Sándalo reef was measured with a ruler, which was buried down to the hard bottom. Data was normalized using logarithm in base 10 for the univariate analysis of variances (ANOVA) between sites. Following transformation, the error variance of most dependent variables, salinity $(\mathrm{p}=0.09)$, temperature $(\mathrm{p}=0.28)$ and organic matter $(\mathrm{p}$ $=0.42$ ), after the Levene's Test, was equalized across the sites; only the error variance of visibility was still not equal across sites $(p<0.05)$. Bonferroni was used as post hoc test for pair wise comparisons of a rather small database with a $0.05 \%$ level of significance.

\section{Non-colonial macro-borers extraction}

All three reefs are relatively shallow and the dominant coral species was Porites lobata Dana (Cortés and Murillo 1985). Fourteen fragments of this coral were collected per site, approximately $1000 \mathrm{~cm}^{3}$ each: seven with less than $50 \%$ and seven with more than $50 \%$ of coral mortality. These samples were collected from Platanillo at 5 to $10 \mathrm{~m}$ depth, from Punta Islotes at 6 to $12 \mathrm{~m}$, and from Sándalo at 3 to $6 \mathrm{~m}$ deep during high tide.

Most studies on macro-bioerosion report borer density values by coral area, however Hutchings and Peyrot-Clausade (1988) report coral macro-borer density by coral volume. Therefore, for comparative purposes, coral fragment areas and volumes were determined.

Coral fragments were later decalcified with a $5 \%$ solution of formalin acidified with nitric acid at $4 \%$ by volume, with daily replacements (Brock and Brock 1977, Hutchings and Weate 1978). This technique, aimed at dissolving the aragonite coral skeleton whilst preserving the calcite bivalve shells, was not successful. Bivalve shells were dissolved anyway thus making species identifications difficult. Noncolonial macro-borers were extracted from the organic matrix, identified, counted and stored in 70\% ethanol at the Zoology Museum, School of Biology, University of Costa Rica. It is recommended for future research on identification of boring bivalves to extract them by physically destroying the coral fragments.

Densities of the major groups of noncolonial macro-borers (bivalves, sipunculans, polychaetes, crustaceans and total densities) were $\log$ normalized. The Box's Test confirmed the equality of covariance matrices $(p=0.13)$. Following transformation, the error variance of most dependent variables, bivalves ( $\mathrm{p}=$ $0.16)$, sipunculans $(\mathrm{p}=0.05)$, polychaetes $(\mathrm{p}$ $=0.34)$ and total densities $(p=0.17)$, after the Levene's Test, was equalized across the sites; only the error variance of crustaceans densities was still not equal across sites $(\mathrm{p}<0.05)$. Since there was correlation between the dependent variables, after the Bartlett's test $(\mathrm{p}<0.05)$, the significance of the differences between sites and coral mortality categories was tested by MANOVA, reporting the Wilks' Lambda test.

Multivariate tests showed that the combined dependent variables of macro-borer densities were significantly affected by each group 
and their interaction, with stronger association of the dependent variables with sites (Value $=0.56)$ than with the extent of coral mortality (Value $=0.36$ ); the Wilks' criterion for the effects of sites is $\mathrm{F}=2.17, \mathrm{df}=10,64 ; \mathrm{p}<0.05$, and for the effect of coral mortality categories it is $\mathrm{F}=11.57, \mathrm{df}=5,32 ; \mathrm{p}<0.05$. Since the interaction between sites and coral mortality categories was significant $(\mathrm{F}=3.08, \mathrm{df}=10$, 64; $\mathrm{p}<0.05$ ), a full factorial model was used for the analysis.

The pair wise comparison between sites was done by the Bonferroni test with a significance level of $0.05 \%$. In the descriptive statistics total mean values by site correspond to the sum of values from live and dead colonies. The Morisita similarity index and the ShannonWienner diversity index (H') with logarithm in base 2 were also estimated, and a student- $t$ test was done to determine the significance of the indexes differences between sites and coral mortality categories.

\section{RESULTS}

\section{Reef relative cover, coral diversity and structural relief}

The Wilks' Lambda multivariate test shows that the combined dependent variables (substrate cover categories) were significantly affected by the group sites ( $\mathrm{F}=7.74$, df $=10$, $100 ; \mathrm{p}<0.05)$. The tests of between subjects effects show that only dead coral cover $(\mathrm{F}=$ $0.04, \mathrm{df}=2,54 ; \mathrm{p}=0.96)$ and sediment cover $(\mathrm{F}=3.11, \mathrm{df}=2,54 ; \mathrm{p}=0.05)$ densities were not significantly different between sites. The differences of live coral cover $(\mathrm{F}=5.98, \mathrm{df}=$
2, 54; $\mathrm{p}<0.05)$, algae cover $(\mathrm{F}=27.97, \mathrm{df}=$ $2,54 ; \mathrm{p}<0.05)$ and coverage by other organisms $(\mathrm{F}=4.69$, df $=2,54 ; \mathrm{p}<0.05)$ were significant between sites. Pair wise comparisons showed that in Platanillo live coral relative cover was higher than in Sándalo and Punta Islotes $(p<0.05)$, with no significant difference between the last two sites $(p=1)$; algae cover was lower in Sándalo than in the other sites $(\mathrm{p}<0.05)$, with no significant difference between Platanillo and Punta Islotes $(p=0.05)$. Coverage by other reef organisms was significantly higher in Punta Islotes $(p<0.05)$, especially by the presence of anemones, than in the other two sites, but not different between Sándalo and Platanillo $(\mathrm{p}=1)$ (Table 1).

The corals diversity (Mean: $0.38 \pm 0.47, \mathrm{n}$ $=36$ ) and structural relief (Mean: $1.28 \pm 0.22, \mathrm{n}$ $=36$ ) were relatively low, and not significantly different between sites after the multivariate tests $(\mathrm{F}=0.28, \mathrm{df}=4,64 ; \mathrm{p}=0.89)$. The tests of between subjects effects show that corals diversity $(\mathrm{F}=0.20, \mathrm{df}=2,33 ; \mathrm{p}=0.82)$ and structural relief $(\mathrm{F}=0.40, \mathrm{df}=2,33 ; \mathrm{p}=0.67)$ were not significantly different between sites.

\section{Water and sediment physical and chemical analysis}

Water visibility showed a significant difference between sites $(\mathrm{F}=4.27, \mathrm{df}=2,10 ; \mathrm{p}<$ $0.05)$. It was considerably lower at Sándalo than at Platanillo $(\mathrm{p}<0.05)$, with no significant differences between Punta Islotes and Sándalo $(\mathrm{p}=$ 0.27 ), and between Punta Islotes and Platanillo $(\mathrm{p}=0.57)$. Water salinities and temperatures were not significantly different between sites $(\mathrm{F}$ $=0.57, \mathrm{df}=2,8 ; \mathrm{p}=0.58$ and $\mathrm{F}=0.91, \mathrm{df}=2$, $8 ; \mathrm{p}=0.44$, respectively) (Table 2 ).

TABLE 1

Reef substrate relative cover at the studied sites (standard deviation in parenthesis)

$\begin{array}{lccccc}\text { Site } & \text { \% Live coral } & \text { \% Dead coral } & \text { \% Algae } & \text { \% Sediment } & \text { \% Others } \\ \text { Platanillo }(\mathrm{n}=19) & 24.35(13.66) & 50.54(18.27) & 6.93(6.59) & 18.18(14.20) & 0.00 \\ \text { Punta Islotes }(\mathrm{n}=19) & 9.94(6.56) & 57.70(23.73) & 12.25(9.40) & 17.63(24.43) & 2.48(5.76) \\ \text { Sándalo }(\mathrm{n}=19) & 16.72(19.85) & 50.88(25.45) & 0.21(0.91) & 32.19(25.57) & 0.00\end{array}$


TABLE 2

Water physical and chemical variables by site

Variable

Maximum coral growth depth (m)

Visibility (m)

Water salinity (PSU)

Water temperature $\left({ }^{\circ} \mathrm{C}\right)$

Sediment type

Main grain size $(\mathrm{mm})$

$\%$ Fine $(<0.075 \mathrm{~mm})$

$\%$ Sand $(0.075-1.000 \mathrm{~mm})$

$\%$ Gravel $(>1.000 \mathrm{~mm})$

$\%$ Organic Matter
Platanillo

10

$11.1 \pm 0.9 \mathrm{~m}, \mathrm{n}=3$

$29.5 \pm 3.3 \mathrm{n}=4$

$28.0 \pm 0.4, n=3$

Poorly graded sand

4.09 (1.18), $\mathrm{n}=4$

$1.12(0.22), \mathrm{n}=4$

$97.47(0.74), \mathrm{n}=4$

$1.42(0.64), \mathrm{n}=4$

$0.32(0.05), \mathrm{n}=6$

Sediments consisted mainly of coralline sand at Platanillo, coralline sandy gravel at Punta Islotes and sandy clays at Sándalo. The difference in sediment size between the Platanillo and Islotes was not significant $(\mathrm{F}=$ $0.28, \mathrm{df}=1,4 ; \mathrm{p}=0.62)$; since in Sándalo sediments were mainly mud, the mean grain size was not reported. Fine sediment $(\mathrm{F}=31.89$, $\mathrm{df}=2,4 ; \mathrm{p}<0.05)$ and gravel $(\mathrm{F}=32.83, \mathrm{df}$ $=2,4 ; \mathrm{p}<0.05)$ were significantly different between sites; whereas content of sand was not $(\mathrm{F}=3.72, \mathrm{df}=2,4 ; \mathrm{p}=0.12)$. There were not enough samples for the post hoc test but, from the descriptive statistics and the visual interpretation, it was noted that amounts of fine sediments were higher at Sándalo than at the other reefs, and gravel was higher at Punta Islotes than at the other reefs. Much of the Sándalo reef was buried by a clay layer, apparently of terrestrial origin, whose mean depth was $38 \mathrm{~cm}$ and reached up to $1 \mathrm{~m}$ deep in some sections of the reef. This clay layer was not found in any of the other reefs. Organic matter in sediments was significantly different between sites $(\mathrm{F}=20.72$, $\mathrm{df}=2,11, \mathrm{p}<0.05)$. Bonferroni post hoc test shows that the organic matter content in sediments was significantly higher in Sándalo than in Punta Islotes and Platanillo $(\mathrm{p}<0.05)$, with no significant differences between the last two sites (Table 2).

\begin{tabular}{rr}
\multicolumn{1}{c}{ Punta Islotes } & \multicolumn{1}{c}{ Sándalo } \\
12 & \multicolumn{1}{c}{6} \\
$6.2 \pm 2.6 \mathrm{~m}, \mathrm{n}=6$ & $3.7 \pm 3.3 \mathrm{~m}, \mathrm{n}=4$ \\
$29.8 \pm 1.1, \mathrm{n}=5$ & $27.6 \pm 3.7, \mathrm{n}=3$ \\
$29.5 \pm 1.8, \mathrm{n}=5$ & $29.3 \pm 1.5, \mathrm{n}=3$ \\
Well graded sandy gravel & Sandy clays \\
$9.00(9.90), \mathrm{n}=3$ & $<0.075, \mathrm{n}=3$ \\
$4.84(3.53), \mathrm{n}=3$ & $51.12(10.30), \mathrm{n}=3$ \\
$40.68(35.16), \mathrm{n}=3$ & $39.58(1.14), \mathrm{n}=3$ \\
$54.48(38.69), \mathrm{n}=3$ & $9.30(0.40), \mathrm{n}=3$ \\
$0.45(0.14), \mathrm{n}=6$ & $0.97(0.03), \mathrm{n}=3$
\end{tabular}

\section{Non-colonial macro-borers diversity, density and relative abundance}

Sixteen species were added to the eastern Pacific coral macro-borers list of Fonseca and Cortés (1998): one barnacle, Weltneria sp., one sipunculan reported for the eastern Pacific for the first time, Phascolosoma nigrescens, and six polychaete species, Dodecaceria concharum, Eunice afra, Lysidice ninetta, Dorvillea (Schistomeringos) annulata, D. (Dorvillea) cerasina and Loanone sp. Most species were found in dead coral colonies or in the dead bases of live coral colonies. Four additional species of bivalves Lithophaga spatiosa, Leiosolenus hanckoki (in Keen 1971), Lithophaga calyculata and Lithophaga hastasia, and four sipunculans: Paraspidosiphon klunzingeri, Phascolosoma puntarenae, Apidosiphon steenstrupii and Sipunculus sp. (in Cantera et al. 2003), not included in Fonseca and Cortés (1998), were found in the literature. The polychaetes Palola siciliensis and Notaulax nudicollus were also found but they are considered only surface bioeroders and not borers.

Fonseca and Cortés (1998) presented the distribution of most eastern Pacific macro-borers. In the present study, the distribution and biogeographic affinities of the additional species were analyzed. The bivalves Lithophaga spatiosa, 
L. hastasia, L. calyculata and Leiosolenus hanckoki, two sipunculans Phascolosoma puntarenae and Paraspidosiphon klusingeri, the polychaete Dorvillea (Schistomeringos) annulata, and the crustaceans Pomatogebia rugosa and $P$. cocosia are endemic to the eastern Pacific; two sipunculans Phascolosoma perlucens and $P$. nigrescens are cosmopolitan (Cutler et al. 1992, Perry 1998, Dean 2001); the bivalve Gastrochaena hians, which according to Kleeman (1990) is a synonym of $G$. cuneiformes, is also present in the Caribbean (Abbot 1974); the sipunculan Aspidosiphon (P.) steenstruppi is present in the Indo-Pacific, Caribbean and eastern Atlantic, the barnacle Weltneria sp. and the polychaete species, Eunice afra and Lysidice ninetta are cosmopolitan (Vittor 1975, Fauchald 1977). Dodecaceria concharum is also reported from the western Atlantic (Blake 1995), while Dorvillea (Dorvillea) cerasina from the western Atlantic and the Caribbean Sea (Fauchald 1977). High macro-borer endemism $(12 \%)$ and greater affinity were found with the western Pacific and Indian oceans (34\%) than with the Mediterranean and eastern Atlantic (29\%), and the western Atlantic and Caribbean (27\%).
Eleven macro-borer families were found in this study (Table 3). At Golfo Dulce all these families were present with the exception of Phascolosomatidae. At Platanillo all these families occurred except for Flabelligeridae and Upogebiidae. Additionally, a family of barnacles (Lithoglypteridae) was found, but not quantified. The study sites have nine macroborers families in common. The Morisita similarity index was higher between Platanillo and Punta Islotes (0.92), then between Sándalo and Punta Islotes (0.84) and it was lowest between Platanillo and Sándalo (0.81). The dominant families at the three reefs were Mytilidae, Aspidosiphonidae, and Eunicidae. Mytilids were common at Sándalo. Gastrochaenid bivalves, dorvilleid, cirratullid, spionid and flabelligerid polychaetes were abundant at Punta Islotes; aspidosiphonids and phascolosomatid sipunculans, and eunicid and sabellid polychaetes were found primarily at Platanillo.

The Shannon-Wienner diversity index $\left(\mathrm{H}^{\prime}\right)$, based on the number of individuals by macro-borers family, calculated for corals less than $50 \%$ dead, increased with increasing level of site degradation $(p<0.001)$. Diversity in coral more than $50 \%$ dead and total diversity was significantly higher at Punta Islotes, followed

TABLE 3

Macro-borers mean density (ind. $/ 100 \mathrm{~cm}^{2}$ ) at family level by site (standard deviation in parenthesis)

$\begin{array}{lccc}\text { MACROBORER } & \text { Platanillo }(\mathrm{n}=18) & \text { Punta Islotes }(\mathrm{n}=18) & \text { Sándalo }(\mathrm{n}=17) \\ \text { BIVALVES } & & & \\ \text { Mytilidae } & 20.9(20.6) & 36.0(30.2) & 53.0(40.3) \\ \text { Gastrochaenidae } & 0.2(0.5) & 6.4(5.6) & 3.9(3.7) \\ & & & \\ \text { SIPUNCULANS } & & 54.6(97.3) & 0.4(1.2) \\ \text { Aspidosiphonidae } & 102.0(153.4) & 2.0(5.1) & \\ \text { Phascolosomatidae } & 1.3(3.6) & & 0.3(0.4) \\ & & & \\ \text { CRUSTACEANS } & 0.0 & 0.3(0.8) & 5.8(8.4) \\ \text { Upogebiidae } & & & 1.1(1.6) \\ & & 13.1(16.7) & 0.6(1.6) \\ \text { POLYCHAETES } & 15.7(30.3) & 2.4(2.5) & 1.7(2.4) \\ \text { Eunicidae } & 1.6(3.3) & 5.4(18.9) & 0.4(0.9) \\ \text { Dorvilleidae } & 0.3(0.8) & 0.9(2.0) & 0.1(0.3) \\ \text { Cirratulidae } & 1.9(3.9) & 1.0(1.7) & \\ \text { Sabellidae } & 0.5(1.1) & 0.2(0.5) & \\ \text { Spionidae } & 0.0 & & \\ \text { Flabelligeridae } & & & \end{array}$


by Sándalo, and finally by Platanillo $(\mathrm{p}<0.001)$. Total diversity was higher in coral more than $50 \%$ dead than in coral less than 50\% dead at all three sites $(\mathrm{p}<0.05)$ (Table 4).

The test of between subjects effects showed that only sipunculan $(\mathrm{F}=5.21, \mathrm{df}=2$, $36 ; \mathrm{p}<0.05)$ and crustacean $(\mathrm{F}=4.62, \mathrm{df}=2$, $36 ; \mathrm{p}<0.05)$ densities were significantly different between sites. Based on the Bonferroni post hoc test, sipunculan densities were significantly higher in Platanillo than in Sándalo and crustacean densities were significantly higher in Sándalo than in Platanillo $(\mathrm{p}<0.05)$, but still low. Bivalve $(\mathrm{F}=0.44, \mathrm{df}=2,36 ; \mathrm{p}$ $=0.64)$, polychaete $(\mathrm{F}=2.16, \mathrm{df}=2,36 ; \mathrm{p}=$ $0.13)$ and total macro borer densities $(\mathrm{F}=1.40$, $\mathrm{df}=2,36 ; \mathrm{p}=0.26$ ) showed no significant difference between sites. There were significant differences between both coral mortality categories for sipunculan $(\mathrm{F}=8.36, \mathrm{df}=1,36$; $\mathrm{p}<0.05)$ and total macro borer densities ( $\mathrm{F}$ $=12.77, \mathrm{df}=1,36 ; \mathrm{p}<0.05)$. The densities of these organisms were higher in coral colonies with higher mortality (50-100\%). There was no significant relationship for bivalve ( $\mathrm{F}$ $=0.88, \mathrm{df}=1,36 ; \mathrm{p}=0.36)$, polychaete $(\mathrm{F}$ $=1.95, \mathrm{df}=1,36 ; \mathrm{p}=0.17)$ and crustacean densities $(\mathrm{F}=0.55, \mathrm{df}=1,36 ; \mathrm{p}=0.46)$ with extent of coral mortality (Table 4 ).

Bivalves were the dominant macro-borer group in Sándalo, while Punta Islotes and Platanillo coral colonies were dominated by sipunculans. Total bivalve relative abundance tended to increase while total sipunculan relative abundance tended to decrease with increasing level of site degradation. Bivalves were dominant in coral colonies with less than $50 \%$ mortality in the three sites, and in coral colonies with more than 50\% mortality in Sándalo. Sipunculans were dominant in coral colonies with more than 50\% mortality in Punta Islotes and Platanillo (Fig. 2).

\section{DISCUSSION}

\section{Reef status}

Traditionally, such factors as high live coral cover and low suspended matter have been considered indicators of good reef health (Highsmith 1980, Pearson 1981, Highsmith et al. 1983, Yap 1986, Birkeland 1997). Based on these traditional factors, many authors consider

TABLE 4

Macro-borers phyla mean density (ind. $/ 100 \mathrm{~cm}^{2}$ ) and families diversity (H': Shannon Wiener diversity index; S: number of families; $N$ : number of individuals) by site and by coral mortality category (standard deviation in parenthesis)

\begin{tabular}{|c|c|c|c|c|c|c|c|c|c|}
\hline Site & $\begin{array}{c}\text { Coral mortality } \\
\text { category }\end{array}$ & Bivalves & Sipunculans & Polychaetes & Crustaceans & Total & S & $\mathrm{N}$ & $\mathrm{H}^{\prime}$ \\
\hline \multicolumn{10}{|c|}{ Platanillo } \\
\hline & $0-50 \%(n=7)$ & $21.1(26.0)$ & $1.1(1.8)$ & $0.9(2.0)$ & 0.0 & $23.1(28.9)$ & 5 & 290 & 0.73 \\
\hline & $50-100 \%(n=7)$ & $29.2(16.2)$ & $261.4(141.6)$ & $49.9(42.1)$ & 0.0 & $340.5(167.2)$ & 9 & 3247 & 1.27 \\
\hline & Weighed mean $(n=14)$ & $25.2(21.2)$ & $131.2(165.8)$ & $25.4(38.3)$ & 0.0 & $181.8(98.05)$ & 9 & 2120 & 1.45 \\
\hline \multicolumn{10}{|c|}{ Punta Islotes } \\
\hline & $0-50 \%(n=7)$ & $55.8(34.2)$ & $2.6(3.1)$ & $6.2(6.7)$ & $0.5(1.1)$ & $65.2(39.8)$ & 10 & 1234 & 1.33 \\
\hline & $50-100 \%(n=7)$ & $31.2(31.4)$ & $102.5(111.9)$ & $41.2(36.7)$ & 0.0 & $174.9(153.8)$ & 10 & 2557 & 1.98 \\
\hline & Weighed mean $(n=14)$ & $43.5(34.0)$ & $52.6(92.0)$ & $23.7(31.1)$ & $0.2(0.8)$ & $52.5(96.8)$ & 11 & 3604 & 2.16 \\
\hline \multicolumn{10}{|c|}{ Sándalo } \\
\hline & $0-50 \%(n=7)$ & $67.3(57.7)$ & $18.6(45.7)$ & $7.9(7.4)$ & $0.2(0.5)$ & $93.9(92.1)$ & 11 & 1377 & 1.53 \\
\hline & $50-100 \%(\mathrm{n}=7)$ & $57.1(23.4)$ & $38.6(55.6)$ & $11.9(17.1)$ & $0.4(0.4)$ & $108.0(57.2)$ & 11 & 1511 & 1.87 \\
\hline & Weighed mean $(n=14)$ & $62.2(42.6)$ & $28.6(50.0)$ & $9.9(12.8)$ & $0.3(0.4)$ & $101.0(74.6)$ & 11 & 4492 & 1.76 \\
\hline \multicolumn{10}{|c|}{ Weighed mean } \\
\hline & $0-50 \%(\mathrm{n}=21)$ & $48.1(44.2)$ & $7.4(26.4)$ & $5.0(6.4)$ & $0.2(0.7)$ & $60.7(53.6)$ & - & - & - \\
\hline & $50-100 \%(n=21)$ & $39.2(26.6)$ & $134.1(141.1)$ & $34.4(36.0)$ & $0.1(0.3)$ & $207.8(126.1)$ & - & - & - \\
\hline
\end{tabular}




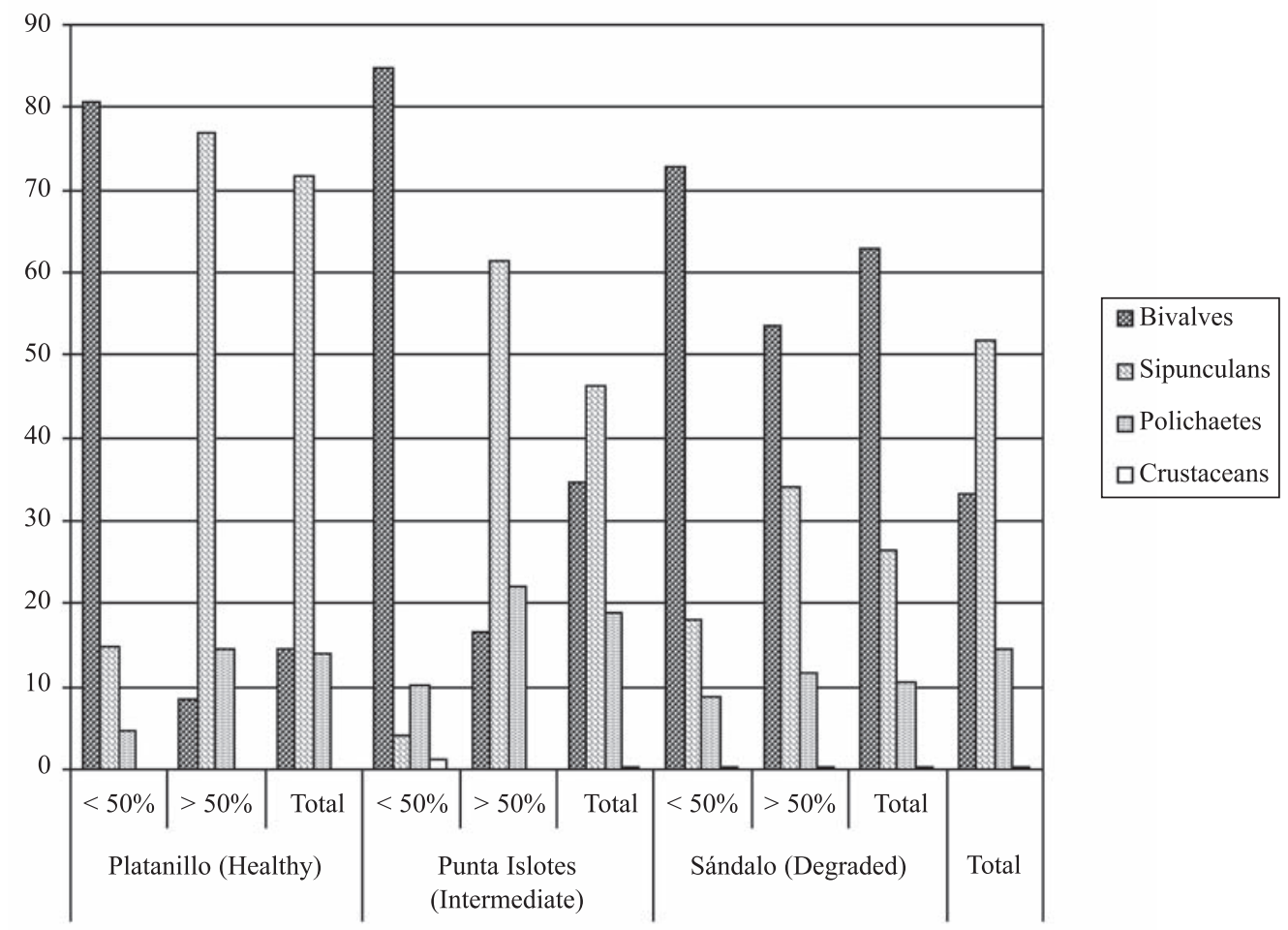

Site and mortality category

Fig. 2. Non-colonial macro-borers relative abundance (expressed as \% of total macro-borers density) by site and coral mortality category.

that continental coral reef growth have been affected by human disturbance, primarily terrestrial sediments (Wilkinson 1992, Guzmán and Cortés 1993).

In the reefs of Golfo Dulce, the relative live coral was significantly lower, water visibility was significantly lower, and the content of mud and organic matter was significantly higher than in Platanillo. At Punta Islotes there was a high proportion of dead coral in the form of gravel. This is due to reduced densities of the once abundant Pocillopora damicornis, which was affected by fresh water and sediment load increases (Cortés 1991, Cortés et al. 1994). Between 1992 and 1996 live coral cover in Sándalo decreased from 29 to $17 \%$, in Punta Islotes it increased from 2 to $10 \%$, while in Platanillo it decreased from 30 to $24 \%$, but cover was still relatively high in Platanillo (Guzmán 1986, Cortés 1992, Fonseca 1999).
At Sándalo and Punta Islotes the mean Secchi disk depth (3.7 and $6.2 \mathrm{~m}$ respectively) was just over half than the maximum coral growth depth in each site (6 m and $12 \mathrm{~m}$ respectively). Light at these reefs was apparently a limiting factor. At Platanillo light penetrates at least up to the maximum coral growth depth $(11 \mathrm{~m})$. The temperature at all sites was adequate for coral reef growth but close to the upper tolerance limit, especially if salinity was low. This is a threat to coral reefs at Sándalo, whose salinity tends to be lower due to its proximity to the Tigre River.

The main problem in Golfo Dulce is the high load of clays that are affecting light penetration in the reef environment. The terrestrial sediments at Golfo Dulce originate from deforested soils exposed almost all yearround to high precipitation, with large run off to rivers and coastal waters (Cortés 1992). Sediments from terrestrial inputs are almost 
always associated with high nutrient and organic matter concentrations (Guzmán and Cortés 1993), which could reduce live coral cover and diversity (Loya 1976), favor the invasion by opportunistic organisms like macro-borers and increase the destruction rates (Pastorok and Bilyard 1985, Hassan 1997). The influence of sediment was higher at Sándalo because it is closer to the Tigre River mouth than Punta Islotes is to the Esquinas River mouth (Umaña 1998). Platanillo was relatively free from this problem since Caño Island has high vegetative cover (Guzmán 1986).

Hurricane Caesar in 1996 also generated very high sediment loads in rivers and coastal areas around Golfo Dulce. It buried most of the reef at Sándalo. In a preliminary granulometric analysis made by the first author in 1993 at the same depth, a higher percentage of gravels $(31.09 \%)$, a similar percentage of sands $(38.75 \%)$ and a lower fines percentage $(30.11 \%)$ were found compared to the sediment collected during the present study. A similar study was done at four reefs in Saint Lucia, situated at different distances from rivers, where the effect of the discharged sediment after hurricane Debbie (September 9, 1994) was measured (Sladek et al. 1997). In Saint Lucia, at sites $0.5 \mathrm{~km}$ from a river, sedimentation rates varied between 11.71 and $64.32 \mathrm{mg}$ $\mathrm{cm}^{-2}$ day $^{-1}$ and the mean clay layer was up to $0.5 \mathrm{~m}$ thick. At Sándalo, situated $0.5 \mathrm{~km}$ away from the river, after hurricane Caesar, the mean thickness of the clay layer $(0.38 \mathrm{~m})$ was similar to Saint Lucia.

Reefs at Caño Island are protected by national laws due to its classification as a Biological Reserve, so the forest cover remains intact. Physic-chemical water variables were adequate for coral growth. These reefs could be considered healthy because they are not directly exposed to the more devastating chronic anthropogenic impacts like terrestrial sediments. Tourism is increasing and the island has been exposed to several warming events associated to El Niño with intense effects (Glynn et al. 1988, Guzmán and Cortés 2001).
Based upon these traditional indicators of degradation (Yap 1986) the reefs at Caño Island are in better condition than those at Golfo Dulce.

\section{Richness, distribution and biogeographic affinities of eastern Pacific macro-borers}

There are 36 colonial and non-colonial macro-borers species reported for the eastern Pacific, with the 18 species added to the list of Fonseca and Cortés (1998). However, there might be still many borers not identified (ex. Porifera).

Sipunculans were frequently found associated with boring sponges that were using the same coral substrate. Apparently sponges provide them with plankton and other organic particles (Wendt et al. 1985) and sipunculans prefer to inhabit areas already weakened by other organisms (Rice 1969, MacGeachy and Stearn 1976).

This study confirms the higher affinity of eastern Pacific marine fauna with other regions within the Indo-Pacific than with regions of the Caribbean and the Atlantic (Cortés 1986, 1997, Lessios et al. 1996). This is a further reason to support Dana's (1975) biogeographic hypothesis of transoceanic transport of larvae from the western to the eastern Pacific by the equatorial counter-current. On the other hand, the eastern Pacific potential for endemism is high relatively to the rest of the Indo-Pacific because dispersion is more restricted by marine currents (Reaka-Kudla 1991). However this could be a biased result derived from the absence of bioerosion studies in many localities.

\section{Non-colonial macro-borers diversity, relative abundance and density}

Macro-borers diversity and densities in coral with more live surface, and bivalve density and relative abundance independent of coral mortality, were higher in the most degraded sites of Golfo Dulce than in Caño Island. Whereas in coral with high mortality, total density especially sipunculans 
density and relative abundance, was higher in Caño Island.

At Platanillo and Punta Islotes, macro-borers diversity tended to be greater in coral with higher mortality. At all sites, total density, especially sipunculan density and relative abundance, was higher in coral more than $50 \%$ dead than in coral less than 50\% dead. Many authors agree that coral mortality favors bioerosion since some space is being released for borers to colonize (MacGeachy and Stearn, 1976; Hutchings 1986; Peyrot-Clausade and Brunel 1990, Peyrot-Clausade et al. 1992). However, at Sándalo coral mortality showed little effect over the macro-borers composition. Bivalve density and relative abundance was even higher in coral with higher live cover, and the species from live coral, such as L. laevigata, are replaced by species from dead coral bases, e.g. L. aristata and L. plumula, when the coral die.

At the three sites, bivalves were very abundant (Fig. 2). Due to their larger size relative to sipunculans and polychaetes, it is suggested that bivalves are responsible for the greatest proportion of internal bioerosion in the eastern as well as the western Pacific. However, bivalves were more abundant and upogebid crustaceans were found only at Golfo Dulce (Table 3). Both feed on suspended organic matter associated with mud (Williams 1986). On the other hand, the sipunculan Phascolosoma elegans was present at Platanillo but was not found in Golfo Dulce. One reason for this could be that these organisms prefer high surge areas and prefer to feed on organic residues associated with sandy sediment (Rice and Macintyre 1972, PeyrotClausade and Brunel 1990). Peyrot et al. (1992) found in Moorea, French Polynesia, in agreement with this study, that the sipunculans (mainly Aspidosiphon elegans) were dominant in colonies of $P$. lobata more than $50 \%$ dead.

Some of the macro-borer families found in this study are also found in other reef provinces. However, direct comparisons of composition and density are difficult because these parameters depend on many variables such as coral surface area, epilithic cover, lithobiont interaction, coral mortality time, and colonization and boring rates, which are determinant factors for the lithobiontic association age (Hutchings and Weate 1978). Sipunculans have the highest relative abundance in most reefs of the IndoPacific, French Polynesia in the central Pacific (Hutchings and Peyrot-Clausade 1988), Great Barrier Reef in the western Pacific (Hutchings and Peyrot-Clausade 1988), Madagascar in the Indian Ocean (Peyrot-Clausade and Brunel 1990), and Platanillo and Punta Islotes in the eastern Pacific (this study). Moreover this fact does not reflect bioerosion magnitude since bivalves, due to their larger size, could occupy more volume despite a lower abundance as is seen in Platanillo. At Enewetak, Marshall Islands, Highsmith (1981b) found that the relative abundances of sipunculans, polychaetes and crustaceans were similar and bivalve abundances were low. Boring sponges are dominant in reefs from the Caribbean (Highsmith et al. 1983, Perry 1998) and Enewetak in the central Pacific (Highsmith 1981b). However, considering only non-colonial macro-borers, the worms are dominant (Highsmith et al. 1983, Wendt et al. 1985, Scott 1987).

Polychaete densities in corals with greater than $50 \%$ dead substrate were lower and sipunculan densities were similar to densities reported from other dead substrate reefs in the central Pacific and Indian Ocean (Kohn and Lloyd 1973, Kohn and White 1977, Pari et al. 1998). The coral reefs of Platanillo and Moorea (Pari et al. 1998) show the highest sipunculan density, perhaps due to their relatively better health. Sándalo, Punta Islotes and Faaa (Pari et al. 1998) show the lowest sipunculan density and, coincidently, these sites are affected by terrestrial sediments.

There is information on boring bivalve densities in coral less than $50 \%$ dead within the eastern Pacific. Bivalves' densities found at Platanillo are similar to those found by Scott et al. (1988) a decade before at the same site. Guzmán (1986) found higher mean bivalve densities in live coral at this reef but within the range of densities of the present study and similar to the mean found at Uva Island, Panama (Scott et al. 1988). Cortés (1992) 
reported a slightly higher bivalve density range from Golfo Dulce. The higher density found by Guzmán (1986) and Cortés (1992) may be explained by the fact that they included only colonies with less than $25 \%$ coral mortality and Guzmán (1986) selected for colonies with high bivalve density. In this study all the colonies less than $50 \%$ dead were included in one category and they were picked at random in the field. Golfo Dulce presented the highest bivalves density for the eastern Pacific in coral less than 50\% dead. The bivalve density in coral less than $50 \%$ dead at Platanillo and Golfo Dulce seems to be higher than the density of this species at reefs with high productivity such as in the Galapagos (Glynn and Wellington 1983).

Considering live and dead corals together, bivalve relative abundance increased and sipunculan relative abundance decreased with increasing reef degradation, but only sipunculan density was significantly different between sites. At the three reefs macro-borers diversity and total density, especially sipunculan density, were higher on coral colonies with more dead than live surface area. In coral with more living surface, macro-borer diversity and total density, especially mytilid density, tended to increase as reef degradation increased. In colonies more than $50 \%$ dead, the total macro-borer density, especially aspidosiphonid density, decreased as reef degradation increased.

The health gradient found between the study reefs based on macro-borer composition and density is the same gradient found considering traditional indicators. In conclusion, macro-borer composition and density, especially that of sipunculans, in live and dead coral could also be used as disturbance bioindicators during coral reef long term monitoring. However, it should be kept in mind that borer communities also have a finite existence related to coral mortality, since dead corals are not building new substrate and borers are destroying the same substrate they need.

\section{AKNOWLEDGMENTS}

Thanks to F. Bolaños, G. Barrantes, J.A. Vargas, A. Morales, M. Peyrot-Clausade, M. Hassan and W. Kiene for all their comments and invested time; to R. Vargas, K. Kleeman, R. Van Syos and A. Williams for the identification of macro-borers. To V. Chazottes, J.-B. Chavarría, S. Lele and R. Bonilla for their help with the statistical analyses; to G. Vargas, C. Durán, E. Ruíz, O. Breedy, R. Valverde, E. Estrada, M. Figueroa, A. L. Araya, S. Solís, K. Arroyo, M. Marín, S. Hernández, T. Aguilar, J. Alvarado and M. Bravo for their help in the field and in the laboratory. To all the staff at CIMAR, the Postgraduate Studies System, and the schools of Biology, Geology and Engineering at the University of Costa Rica for all the logistic support.

\section{RESUMEN}

Se diagnosticó el estado de salud de tres arrecifes del Pacífico sur de Costa Rica, uno en Isla del Caño y dos en Golfo Dulce, y se determinó la densidad, la riqueza y la distribución de los macroperforadores no coloniales $(>1 \mathrm{~mm})$ en fragmentos de coral vivos y muertos. Basándose en los indicadores tradicionales de degradación como alta materia particulada en suspensión y baja cobertura de coral, los arrecifes de Isla del Caño están en mejor condición que los de Golfo Dulce. La degradación en Golfo Dulce se debe principalmente a la gran cantidad de sedimentos terrestres generados por la deforestación de las cuencas de los ríos. En total se han reportado 36 especies de macroperforadores de coral, incluyendo este estudio, para el Pacífico oriental. A nivel de familia hay algo de endemismo (10\%), y una mayor afinidad con el Indo-Pacífico (34\%) que con el Atlántico oriental y el Mediterráneo (29\%) y el Atlántico occidental y el Caribe (27\%). Las familias de macroperforadores no coloniales más dominantes en los arrecifes estudiados son los bivalvos mitílidos, los poliquetos eunícidos y los sipuncúlidos aspidosifónidos. Los bivalvos son considerados los principales bioerosionadores internos debido a su gran tamaño y abundancia. El grado de mortalidad de las colonias coralinas y el nivel general de degradación arrecifal están relacionados con la composición de los macroperforadores no coloniales. La diversidad y la densidad 
total de macroperforadores, especialmente la densidad de aspidosifónidos es mayor en corales con una superficie muerta mayor que la viva. En colonias de coral con una superficie viva de más de $50 \%$, la dominancia de mitílidos, la diversidad de los macroperforadores y la densidad total, son mayores en los arrecifes de Golfo Dulce que están más degradados. En colonias con más del $50 \%$ de mortalidad, la densidad total de macro-perforadores, especialmente aspidosifónidos, es mayor en el arrecife Platanillo de Isla del Caño, el arrecife más saludable de este estudio. La abundancia relativa de los bivalvos aumenta y la de los sipuncúlidos disminuye conforme aumenta la degradación arrecifal. En conclusión, la bioerosión interna se puede utilizar como un indicador de salud arrecifal.

\section{REFERENCES}

Abbot, R.T. 1974. American Seashells. The Marine Mollusca of the Atlantic and Pacific Coasts of North America. Van Nostrand Reinhold Company, New York, USA.

Birkeland, C. 1997. Introduction: 1-2. In Birkeland, C. (ed.). Life and Death of Coral Reefs. Chapman and Hall, New York, USA.

Blake, J.M. 1995. Family Cirratulidae Ryckholdt, 1851. Including a revision of the genera and species from the eastern north Pacific. In J.A. Blake, B. Hilbig \& P.H. Scott (eds.). Taxonomic atlas of the benthic fauna of the Santa María Basin and western Santa Barbara Channel, Vol. 6 - the Annelida part 3. Santa Barbara Mus. Nat. Hist. Santa Barbara, California.

Brock, R.E. \& J.H. Brock. 1977. A method for quantitatively assessing the infaunal community in coral rock. Limnol. Oceanogr. 22: 948-951.

Brock, R.E. \& S.D. Smith. 1983. Response of coral reef cryptofaunal communities to food and space. Coral Reefs 1: 179-183.

Cantera K., J.R. \& R. Contreras. 1988. Bivalvos perforadores de esqueletos de corales escleractinarios en la Isla de Gorgona, Pacífico colombiano. Rev. Biol. Trop. 36: 151-158.

Cantera K., J.R., C. Orozco, E. Londoño-Cruz \& G. ToroFarmer. 2003. Abundance and distribution patterns of infaunal associates and macroborers of the branched coral (Pocillopora damicornis) in Gorgona Island (eastern tropical Pacific). Bull Mar Sci. 72: 207-219.

Chazottes, V., T. Le Campion-Alsumard, M. PeyrotClausade \& P. Cuet. 2002. The effects of eutrophication-related alterations to coral reef communities on agents and rates of bioerosion (Reunion Island, Indian Ocean). Coral Reefs 21: 375-390.
Cortés, J. 1986. Biogeografía de corales hermatípicos: el istmo Centro Americano. An Inst Cienc Mar Limnol, UNAM, 13: 297-304.

Cortés, J. 1990a. Coral reef decline in Golfo Dulce, Costa Rica, Eastern Pacific: anthropogenic and natural disturbances. Ph D. dissert., Univ. of Miami, Miami, Florida. $147 \mathrm{p}$.

Cortés, J. 1990b. The coral reefs of Golfo Dulce, Costa Rica: distribution and community structure. Atoll. Res. Bull. 344: 1-37.

Cortés, J. 1991. Los arrecifes coralinos de Golfo Dulce, Costa Rica: aspectos geológicos. Rev. Geol. Amér. Central 13: 15-24.

Cortés, J. 1992. Los arrecifes coralinos de Golfo Dulce, Costa Rica: aspectos ecológicos. Rev. Biol. Trop. 40: 19-26.

Cortés, J. 1997. Biology and geology of eastern Pacific coral reefs. Coral Reefs 16: S39-S46.

Cortés, J. \& M.M. Murillo. 1985. Comunidades coralinas y arrecifes del Pacífico de Costa Rica. Rev. Biol. Trop. 33: 197-202.

Cortés, J., I.G. Macintyre \& P.W. Glynn. 1994. Holocene growth history of an eastern Pacific fringing reef, Punta Islotes, Costa Rica. Coral Reefs 13: 65-73.

Cutler N..J, E.B. Cutler \& J.A. Vargas. 1992. Peanut worms (Phylum Sipuncula) from Costa Rica. Rev. Biol. Trop. 40: 153-158.

Dana, T. 1975. Development of contemporary eastern Pacific coral reefs. Mar. Biol. 33: 355-374.

Dean, H.K. 2001. Marine biodiversity of Costa Rica: the phyla Sipuncula and Echiura. Rev. Biol. Trop. 49: 85-90.

Dean, W.E., M. Leinen \& D.A.V. Stow. 1985. Classification of deep-sea, fine grained sediments. J. Sediment. Petrol. 55: 250-256.

Eakin, C.M. 1992. Post-El Niño Panamanian reefs: less accretion, more erosion and damselfish protection. Proc 7th Int. Coral Reef Symp. Guam. 1: 387-396.

Eakin, C.M. 1996. Where have all the carbonates gone? A model comparison of calcium carbonate budgets before and after the 1982-1983 El Niño at Uva Island in the eastern Pacific. Coral Reefs 15: 1-11.

Fauchald, K. 1977. Polychaetes from intertidal areas in Panama, with a review of previous shallow water records. Smithson. Contrib. Zool. 221.

Fonseca, A.C. 1999. Bioerosión y bioacreción en arrecifes coralinos del Pacífico sur de Costa Rica. MSc. thesis, Univ. Costa Rica, San José. 206 p. 
Fonseca, A.C. \& J. Cortés. 1998. Coral borers of the eastern Pacific: Aspidosiphon (A.) elegans (Sipuncula: Aspidosiphonidae) and Pomatogebia rugosa (Crustacea: Upogebiidae). Pac. Sci. 52: 170-175.

Glynn, P.W. 1988. El Niño warming, coral mortality and reef framework destruction by echinoid bioerosion in the eastern Pacific. Galaxea 7: 129-160.

Glynn, P.W. 1997. Bioerosion and coral reef growth: a dynamic balance, pp: 68-95. In Birkeland C (ed.) Life and Death of Coral Reefs. Chapman \& Hall, University of Guam.

Glynn, P.W. \& G.M. Wellington. 1983. Corals and Coral Reefs of the Galápagos Islands (with an annotated list of the scleractinian corals of the Galápagos by J.W. Wells). Univ. of California, Berkeley, California, USA.

Glynn, P.W., J. Cortés, H.M. Guzmán \& R.H. Richmond 1988. El Niño (1982-83) associated mortality and relationship to sea surface temperature deviations in the tropical eastern Pacific. Proc. 6th Int. Coral Reef Symp., Australia 3: 237-243.

Guzmán, H.M. 1986. Estructura de la comunidad arrecifal de la Isla del Caño, Costa Rica y el efecto de perturbaciones naturales severas. MSc thesis, Univ. Costa Rica, San José.

Guzmán, H.M. \& J. Cortés. 1989a. Coral reef community structure at Caño Island, Pacific Costa Rica. P.S.Z.N.I: Mar. Ecol. 10: 23-41.

Guzmán, H.M. \& J. Cortés. 1989b. Growth rates of eight species of scleractinian corals in the eastern Pacific (Costa Rica). Bull. Mar. Sci. 44: 1186-1194.

Guzmán, H.M. \& J. Cortés. 1993. Los arrecifes coralinos del Pacífico oriental ecuatorial: revisión y perspectivas. Rev. Biol. Trop. 41: 535-557.

Guzmán, H.M. \& J. Cortés. 2001. Changes in reef community structure after fifteen years of natural disturbances in the eastern Pacific (Costa Rica). Bull. Mar. Sci. 69: 133-149.

Hassan, M. 1997. Modification of carbonate substrata by bioerosion and bioaccretion on coral reefs of the Red Sea. Shager Verlag, Kiel, Germany.

Hebbeln, D., D. Beese \& J. Cortés. 1996. Morphology and sediment structures in Golfo Dulce, Costa Rica. Rev Biol Trop 44 (Suppl 3): 1-10.

Highsmith, R.C. 1980. Geographic patterns of coral bioerosion: a productivity hypothesis. J. Exp. Mar. Biol. Ecol. 46: 177-196.
Highsmith, R.C. 1981a. Coral bioerosion: damage relative to skeletal density. Am. Nat. 117: 193-198.

Highsmith, R.C. 1981b. Coral bioerosion at Enewetak: agents and dynamics. Int. Rev. Ges. Hydrobiol. 66: 335-375.

Highsmith, R.C., R.L. Lueptow \& S.C. Schonberg. 1983. Growth and bioerosion of three massive corals on the Belize Barrier Reef. Mar. Ecol. Prog. Ser. 13: 261-271.

Hughes, T.P. et al. 2003. Climate change, human impacts, and the resilience of coral reefs. Science 301: 929933.

Hutchings, P.A. 1986. Biological destruction of coral reefs: a review. Coral Reefs 4: 239-252.

Hutchings P.A. \& P.B. Weate. 1978. Non-colonial cryptofauna. 581 p. In Stoddart DR, Johannes RE (eds). Coral Reefs: Research Methods. Monograph on Oceanographic Methodology 5, UNESCO, Paris.

Hutchings, P. \& M. Peyrot-Clausade. 1988. Macro-infaunal boring communities of Porites a biogeographical comparison. Proc. 6th Int. Coral Reef Symp., Australia. 3: 263-267.

Hutchings, P.A., W.E. Kiene, R.B. Cunningham \& C. Donnelly. 1992. Spatial and temporal patterns of noncolonial boring organisms (polychaetes, sipunculans and bivalve molluscs) in Porites at Lizard Island, Great Barrier Reef. Coral Reefs 11: 23-31.

Keen, A.M. 1971. Sea Shells of Tropical West America: Marine Mollusks from Baja California to Perú, 2nd ed. Stanford University, Stanford, California. USA.

Kiene, W.E. 1988. A model of bioerosion on the Great Barrier Reef. Proc 6th Int Coral Reef Symp, Australia 3: 449-454.

Kleemann, K. 1990. Boring and growth in chemically boring bivalves from the Caribbean, eastern Pacific and Australia's Great Barrier Reef. Senckenb. Marit. 21: 101-154.

Kohn, A.J. \& M. Lloyd. 1973. Polychaetes of truncated reef limestone substrates on eastern Indian Ocean coral reefs: diversity, abundance, and taxonomy. Int Rev. Ges. Hydrobiol. 58: 369-399.

Kohn, A.J. \& J. White. 1977. Polychaete annelids of an intertidal reef limestone platform at Tanguisson, Guam. Micronesica 13: 199-215.

Lessios, H.A., B.D. Kessing, G.M. Wellington \& A. Graybeal. 1996. Indo-Pacific echinoids in the tropical eastern Pacific. Coral Reefs 15: 133-142. 
Londoño-Cruz E., J.R. Cantera, G. Toro-Farmer \& C. Orozco. 2003. Internal bioerosion by macroborers in Pocillopora spp. in the tropical eastern Pacific. Mar. Ecol. Prog. Ser. 265: 289-295.

Loya, Y. 1976. Effects of water turbidity and sedimentation on the community structure of Puerto Rican corals. Bull. Mar. Sci. 26: 450-466.

Macintyre, I.G., P.W. Glynn \& J. Cortés. 1992. Holocene reef history in the eastern Pacific: mainland Costa Rica, Caño Island, Cocos Island, and Galápagos Islands. Proc. 7th Int. Coral Reef Symp., Guam 2: 1174-1184.

MacGeachy, J.K. \& C.W. Stearn. 1976. Boring by macroorganisms in the coral Montastrea annularis on Barbados reefs. Int. Rev. Ges. Hydrobiol. 61: 715745 .

Mokady, O., Y. Loya \& B. Lazar. 1998. Ammonium contribution from boring bivalves to their coral host-a mutualistic symbiosis? Mar. Ecol. Prog. Ser. 169: 295-301.

Pari, N., M. Peyrot-Clausade, T. Le Campion-Alsumard, P. Hutchings, V. Chazottes, S. Golubic, J. Le Campion \& M.F. Fontaine. 1998. Bioerosion of experimental substates on high islands and on atoll lagoons (French Polynesia) after two years exposure. Mar. Ecol. Prog. Ser. 166: 119-130.

Pastorok, R.A. \& G.R. Bilyard. 1985. Effects of sewage pollution on coral reef communities. Mar. Ecol. Prog. Ser. 21: 175-189.

Pearson, R.G. 1981. Recovery and recolonization of coral reefs. Mar. Ecol. Prog. Ser. 4: 105-122.

Perry, C.T. 1998. Macro-borers within coral framework at Discovery Bay, north Jamaica: species distribution and abundance, and effects on coral preservation. Coral Reefs 17: 277-287.

Peyrot-Clausade, M. \& J.F. Brunel. 1990. Distribution patterns of macroboring organisms on Tuléar reef flats (SW Madagascar). Mar. Ecol. Prog. Ser. 61: 133-144.

Peyrot-Clausade, M., P. Hutchings \& G. Richards. 1992. Temporal variations of macro-borers in massive Porites lobata on Moorea, French Polynesia. Coral Reefs 11: 161-166.

Reaka-Kudla, M.L. 1991. Processes regulating biodiversity in coral reef communities on ecological vs. evolutionary time scales. In Dudley EC (ed.). The Unity of Evolutionary Biology. Proc. 4th Int. Congr. Syst. Evol. Biol. 1: 61-70.
Rice, M.E. 1969. Possible boring structures of sipunculids. Amer. Zool. 9: 803-812.

Rice, M.E. \& I.G. Macintyre. 1972. A preliminary study of sipunculan burrows in rock thin sections. Carib. J. Sci. 12: 1-2.

Risk, M.J. 1972. Fish diversity on a coral reef in the Virgin Islands. Atoll Res. Bull. 153: 1-6.

Scoffin, T.P., C.W. Stearn, D. Boucher, P. Frydl, C.M. Hawkins, I.G. Hunter \& J.K. MacGeachy. 1980. Calcium carbonate budget of a fringing reef on the west coast of Barbados; part II-erosion, sediments and internal structure. Bull. Mar. Sci. 30: 475-508.

Scott, P.J.B. 1987. Associations between corals and macroinfaunal invertebrates in Jamaica, with a list of Caribbean and Atlantic coral associates. Bull. Mar. Sci. 40: 271-286.

Scott, P.J.B. \& M.J. Risk. 1988. The effects of Lithophaga (Bivalvia: Mytillidae) boreholes on the strength of the coral Porites lobata. Coral Reefs 7: 145-151.

Scott, P.J.B., M.J. Risk \& J.D. Carriquiry. 1988. El Niño, bioerosion and the survival of east Pacific reefs. Proc. 6th Int. Coral. Reef. Symp., Australia 2: 517-520.

Sladek, N., J., Roberts, C.M., Smith, A.H. \& E. Siirila. 1997. Human-enhanced impacts of a tropical storm on nearshore coral reefs. Ambio 26: 515-521.

Smith, S.V., W.J. Kimmerer, E.A. Laws, R.E. Brock \& T.W. Walsh. 1981. Kaneohe Bay sewage diversion experiment: perspectives on ecosystem response to nutritional perturbation. Pac. Sci. 35: 279-402.

Umaña, G. 1998. Characterization of some Golfo Dulce drainage basin rivers (Costa Rica). Rev. Biol. Trop. 46 (Suppl. 6): 125-135.

Vittor, B.A. 1975. Preliminary estimates of coral reef infaunal populations at Hydro-Lab, Grand Bahama Island. Hydro-Lab. J. 3: 76-79.

Walkey, A. \& C.A. Black. 1938. An examination of the Degtajareff's method for determining soil organic matter, and proposed modification of the Cromic Acid Titration Method Soil. Science 37: 29-38.

Wilkinson, C.R. 1992. Coral reefs of the world are facing widespread devastation: can we prevent this through sustainable management practices? Proc. $7^{\text {th }}$ Int. Coral Reef Symp., Guam, 1: 11-21.

Williams, A.B. 1986. Mud shrimps, Upogebia, from the eastern Pacific (Thalassinoidea: Upogebiidae). S Diego Soc. Nat. Hist. Mem. 14: 1-60.

Yap, H.T. 1986. Bioindication in coral reef ecosystems. Acta Biol. Hung. 37: 55-58. 
